\title{
Hispolon as an inhibitor of TGF- $\beta$-induced epithelial-mesenchymal transition in human epithelial cancer cells by co-regulation of TGF- $\beta$-Snail/Twist axis
}

\author{
DARONG HONG ${ }^{1}$, MIN-JU PARK ${ }^{2}$, EUN HYANG JANG ${ }^{2}$, BOM JUNG ${ }^{2}$, NAM-JUNG KIM ${ }^{2}$ and JONG-HO KIM ${ }^{2}$ \\ Departments of ${ }^{1}$ Life and Nanopharmaceutical Science and ${ }^{2}$ Pharmacy, Graduate School, \\ Kyung Hee University, Dongdaemun-gu, Seoul 02447, Republic of Korea
}

Received May 2, 2016; Accepted February 13, 2017

DOI: $10.3892 / \mathrm{ol} .2017 .6789$

\begin{abstract}
Hispolon (HPL), isolated from Phellinus linteus, has been used to treat various types of pathology, including inflammation, gastroenteric disorders, lymphatic diseases and numerous cancer subtypes. HPL has previously been reported to demonstrate a significant therapeutic efficacy against various types of cancer cells, including melanoma, leukemia, hepatocarcinoma, bladder and gastric cancer cells However, its potential role in the epithelial-mesenchymal transition (EMT) has not been demonstrated. The present study investigated the effects of HPL on the EMT. Transforming growth factor $\beta$ (TGF- $\beta$ ) induced enhanced cell migration and invasion, EMT-associated phenotypic changes. In the present study, HPL recovered the reduction of E-cadherin expression level in TGF- $\beta$ treated cancer cells, which was regulated by the expression of Snail and Twist. HPL downregulated Snail and Twist, an effect that was enhanced by TGF- $\beta$. These findings provide novel evidence that HPL suppresses cancer cell migration and invasion by inhibiting EMT. Therefore, HPL may be a potent anticancer agent, inhibiting metastasis.
\end{abstract}

\section{Introduction}

Cancer is the second leading cause of death worldwide, accounting for $24 \%$ of total mortalities (1). Approximately $90 \%$ of cancer-associated mortalities are caused by local invasion and distant metastasis of tumor cells; the prognosis of patients with advanced cancer is associated with the degree of aggressive metastasis (2-4). However, the mechanism underlying metastasis of cancer remained unclear, until certain genes associated with metastasis were identified in a previous study (5).

Correspondence to: Professor Jong-Ho Kim, Department of Pharmacy, Graduate School, Kyung Hee University, 26 Kyungheedae-ro, Dongdaemun-gu, Seoul 02447, Republic of Korea

E-mail: jonghokim@khu.ac.kr

Key words: hispolon, epithelial-mesenchymal transition, transforming growth factor $\beta$, migration, invasion
A previous study suggested that the epithelial-mesenchymal transition (EMT), an important morphological event in which polarized epithelial cells convert to contractile and motile mesenchymal cells, is recognized as an important process during metastasis (6). EMT induced the generation of cancer cells with stem cell-like characteristics, including increasing their self-renewal, tumor-initiating capabilities and resistance to apoptosis and chemotherapy, which promoted tumor cell invasion and metastasis (7). During the EMT of cancer cells in situ, epithelial cell layers lose their polarity and cell-cell contacts, undergoing a remodeling of the cytoskeleton (8). The expression levels of proteins, including E-cadherins, that promote cell-cell contact may be lost, enhancing their capacity for cell migration and invasion, which are pivotal events in the initial stage of metastasis $(9,10)$. Therefore, previous studies have investigated the inhibition of EMT of cancer cells as a novel therapeutic target for cancer metastasis $(11,12)$.

Hispolon [6-(3,4-dihydroxy phenyl)-4-hydroxyhexa-3,5-dien-2-one] (HPL), one of the bioactive components isolated from Phellinus linteus, has been reported to possess antioxidant, anti-inflammatory and anti-proliferative properties and to exert protective effects against acute liver damage (13-15). In addition, HPL has demonstrated antitumor effects in various types of cancer cells, including melanoma, leukemia, hepatocarcinoma, bladder cancer and gastric cancer cells (16-20).

The present study hypothesized that HPL is an effective inhibitor of EMT during cancer progression, and may therefore be used as an agent for epithelial tumors. It was revealed in the present study that HPL significantly inhibited the invasion and migration of MCF-7 and A549 human epithelial cancer cells during TGF- $\beta$-induced EMT, by co-regulating the TGF- $\beta$-Snail/Twist signaling axis. Therefore, it was suggested that HPL may be an effective candidate agent for use against tumors due to its inhibition of metastasis.

\section{Materials and methods}

Cell culture and reagents. MCF-7 and A549 cells (American Type Culture Collection, Manassas, VA, USA) were maintained in Dulbecco's modified Eagle's medium (DMEM, HyClone, Logan, UT, USA) supplemented with $10 \%$ fetal bovine serum 
(FBS, HyClone) and $1 \%$ penicillin/streptomycin antibiotics. HPL was purchased from Santa Cruz Biotechnology (Santa Cruz Biotechnology, Inc., Dallas, TX, USA). The antibody for $\beta$-actin was supplied by Santa Cruz Biotechnology, Inc., Snail antibody was purchased from Cell Signaling Technology, Inc. (Danvers, MA, USA) and Twist antibody was obtained from Abcam (Cambridge, MA, USA).

Cell proliferation assay. All proliferation assays were based on the MTT method. Cells were seeded in a 96-well plate ( $1 \times 10^{4}$ cells/well). Following overnight culture, HPL was added to the cells and further cultured for $24 \mathrm{~h}$ at $37^{\circ} \mathrm{C}$. Cells cultured without HPL were used as a control. The media was removed and dimethyl sulfoxide was added to the MTT (Sigma-Aldrich; Merck KGaG, Darmstadt, Germany) solubilization solution. Absorbance was measured at $550 \mathrm{~nm}$. For the colony formation assay, single-cell suspensions of $5 \times 10^{3}$ cells were seeded onto a 6-well plate and allowed to attach for $24 \mathrm{~h}$ at $37^{\circ} \mathrm{C}$ in culture medium. Cells were then treated with 20 or $200 \mu \mathrm{M}$ HPL at $37^{\circ} \mathrm{C}$. Medium containing HPL was refreshed every two days. Following 10 days, colonies were fixed with $100 \%$ methanol for $10 \mathrm{~min}$ and stained with $0.1 \%$ crystal violet at room temperature. Plates were washed with PBS and imaged.

Cell migration assay. Migration was assessed by a wound-healing assay. MCF-7 and A549 cells were seeded at $2 \times 10^{4}$ cells/well and were cultured for $24 \mathrm{~h}$. Following scraping the cell monolayer with a sterile micropipette tip, the wells were washed with PBS, and treated with TGF- $\beta$ (10 ng/ml, R\&D Systems, Inc., Minneapolis, MN, USA) or co-treated with TGF- $\beta(10 \mathrm{ng} / \mathrm{ml})$ and HPL $(20 \mu \mathrm{M})$ for $24 \mathrm{~h}$ at $37^{\circ} \mathrm{C}$. The first image of each scratch was acquired at time zero. At $24 \mathrm{~h}$, each scratch was examined and captured at the same location and the healed area was determined. All captured images were obtained by using a light microscope (Eclipse, Ti-S, Nikon Instruments Inc., NY, USA).

Transwell invasion assay. The invasion of tumor cells was assessed in Transwell chambers (Corning Incorporated, Corning, NY, USA) with $8 \mu \mathrm{m}$ pore size, $6.5 \mathrm{~mm}$ diameter polyvinylpyrrolidone-free polycarbonated membranes that were coated with $1 \mathrm{mg} / \mathrm{ml}$ fibronectin (R\&D Systems, Inc.). The cells were seeded onto the upper wells at a concentration $1 \times 10^{5} \mathrm{MCF}-7$ and A549 cells/well and were cultured for $24 \mathrm{~h}$ at $37^{\circ} \mathrm{C}$ following treatment with TGF- $\beta(10 \mathrm{ng} / \mathrm{ml})$ or co-treatment with TGF- $\beta(10 \mathrm{ng} / \mathrm{ml})$ and HPL $(20 \mu \mathrm{M})$. The bottom chambers of the Transwell were filled with conditioned medium, DMEM. Following incubation for $24 \mathrm{~h}$, cells were fixed with $100 \%$ methanol for $10 \mathrm{~min}$, stained with $0.1 \%$ crystal violet for $5 \mathrm{~min}$ at room temperature and counted under a light microscope.

Western blotting. MCF-7 and A549 cells were treated with TGF- $\beta(10 \mathrm{ng} / \mathrm{ml})$ or co-treated with TGF- $\beta(10 \mathrm{ng} / \mathrm{ml})$ and HPL $(20 \mu \mathrm{M})$ for $24 \mathrm{~h}$ at $37^{\circ} \mathrm{C}$. Following lysis in radioimmunoprecipitation assay buffer (Thermo Fisher Scientific, Inc., Waltham, MA, USA), proteins quantified with BCA protein assay kit (Thermo Fisher Scientific, Inc.) were resolved by $10 \%$ SDS-PAGE gel and immunoblotted with Immobilon-P transfer membrane (EMD Millipore, Billerica, MA,
USA) using primary antibodies including anti-E-cadherin (1:1,000; catalog no. ab184633; Abcam, Cambridge, UK), anti-Snail (1:1,000; Cell Signaling Technology, Inc., catalog no. 3895), anti-Twist (1:1,000; catalog no. ab175430; Abcam) and anti- $\beta$-actin $(1: 1,000$; catalog no. sc47778; Santa Cruz Biotechnology, Inc.) for $2 \mathrm{~h}$ at room temperature. Following treatment with secondary antibodies, goat anti-mouse IgG (1:2,000; catalog no. sc2005; Santa Cruz Biotechnology, Inc.) for $2 \mathrm{~h}$ at room temperature, the immunoreactive bands were visualized using the standard enhanced chemiluminescence method (SuperSignal Est Pico; Thermo Scientific, Inc.).

Immunofluorescence staining. MCF-7 and A549 cells were grown in 4-chamber slides in serum-free media, and were treated with TGF- $\beta(10 \mathrm{ng} / \mathrm{ml})$ or co-treated with TGF- $\beta$ $(10 \mathrm{ng} / \mathrm{ml})$ and HPL $(20 \mu \mathrm{M})$ at $37^{\circ} \mathrm{C}$. Following $24 \mathrm{~h}$, the cells were fixed with $4 \%$ paraformaldehyde for $15 \mathrm{~min}$ at $4^{\circ} \mathrm{C}$. Cells were washed with PBS containing $0.1 \%$ bovine serum albumin (Sigma-Aldrich; Merck KGaA) and incubated with anti-E-cadherin antibody (1:100; catalog no. ab184633; Santa Cruz Biotechnology, Inc.) for $1 \mathrm{~h}$ followed by $1 \mathrm{~h}$ incubation with FITC-tagged goat anti-mouse IgG (1:200; catalog no. sc2010; Santa Cruz Biotechnology, Inc.), then counter-stained with DAPI for $5 \mathrm{~min}$. All staining were procedures performed at room temperature. Cell images were captured at x400 magnification on a Leica fluorescence microscope.

Statistical analysis. The results are presented as the mean \pm standard error, and statistical comparisons between groups were performed using the Student's t-test using SigmaPlot (version 10.0; Systat Software, Inc., San Jose, CA, USA). $\mathrm{P}<0.05$ was considered to indicate a statistically significant difference.

\section{Results}

Effect of HPL on the growth of human cancer cells in vitro. The present study initially examined the effect of HPL on the proliferation of the MCF-7 and A549 human cancer cell lines. To determine the drug concentration that induced $50 \%$ growth inhibition $\left(\mathrm{IC}_{50}\right)$, cells were treated with various concentrations of HPL (1, 2, 5, 10, 20, 50, 100, 200 and $500 \mathrm{mM})$ for $24 \mathrm{~h}$ and cell viability was evaluated by MTT assay. As presented in Fig. $1 \mathrm{~A}, \mathrm{IC}_{50}$ values for both cell types were similar $(\sim 65 \mu \mathrm{M})$. The long-term effects of HPL were determined by culturing MCF-7 and A549 cells with or without HPL for 10 days and then performing colony formation assays. At a concentration of $20 \mu \mathrm{M}, \mathrm{HPL}$ demonstrated a slight inhibitory effect, whereas $200 \mu \mathrm{M}$ HPL almost completely inhibited colony formation (Fig. 1B). Therefore, $20 \mu \mathrm{M}$ HPL was considered to be a suitable dose for subsequent experiments.

Effect of HPL on TGF- $\beta$-induced migration of human cancer cells. TGF- $\beta$ (10 ng/ml) may function as a pro-oncogenic factor through the induction of the EMT process, as previously reported (21). The present study investigated the effects of HPL on cell migration to demonstrate that HPL inhibited TGF- $\beta$-induced EMT as EMT is associated with enhanced tumor progression. Cancer cell lines were treated with TGF- $\beta$ alone, TGF- $\beta$ plus HPL $(20 \mu \mathrm{M})$ or HPL alone 

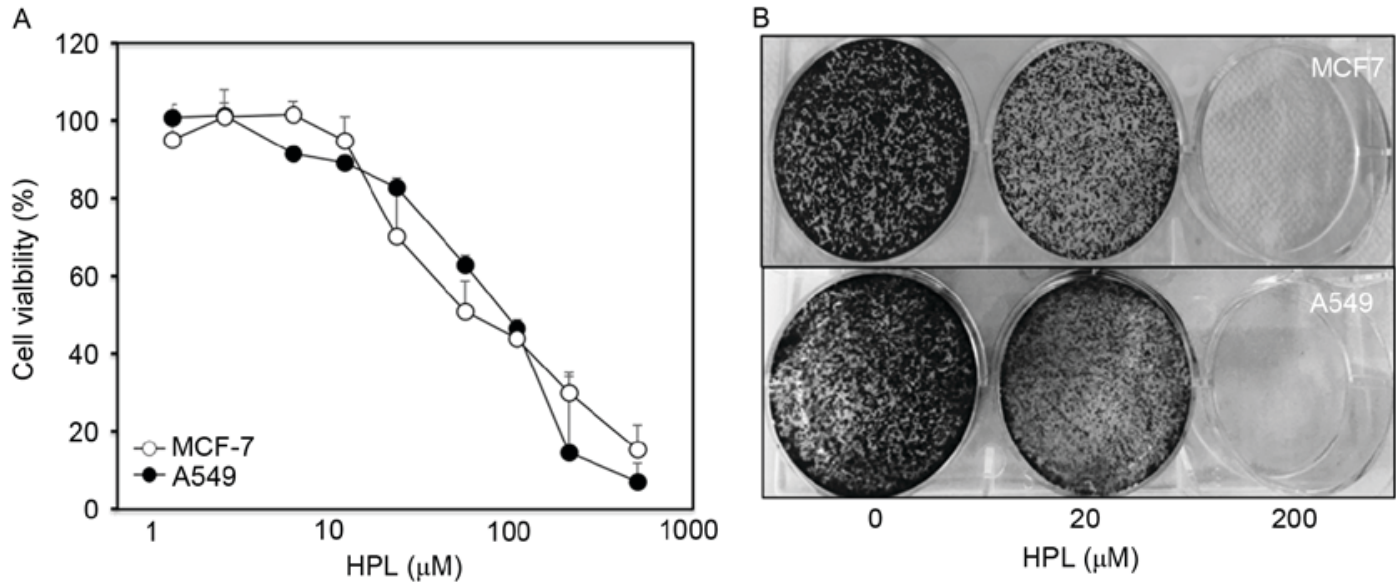

Figure 1. HPL inhibits the growth of human cancer cells. (A) MCF-7 and A549 cells were seeded in a 96-well plate and treated with various concentrations of HPL after $24 \mathrm{~h}$. Cell proliferation was determined by MTT assay. Data are presented as the percentage of proliferation relative to that in the medium-treated controls. The results are expressed as the mean \pm standard deviation of three replicated evaluations from a single experiment, and are representative of three separate experiments. (B) MCF-7 and A549 cells were seeded in a 6-well plate and treated with 0, 20 and $200 \mu$ M HPL for 15 days. Colonies were fixed with $100 \%$ methanol for $10 \mathrm{~min}$ at room temperature and stained with $0.1 \%$ crystal violet. Representative photographs demonstrating colony formation are presented. HPL, hispolon.

A
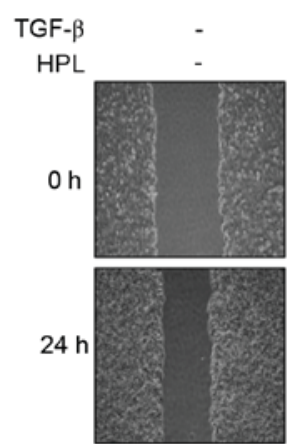

B
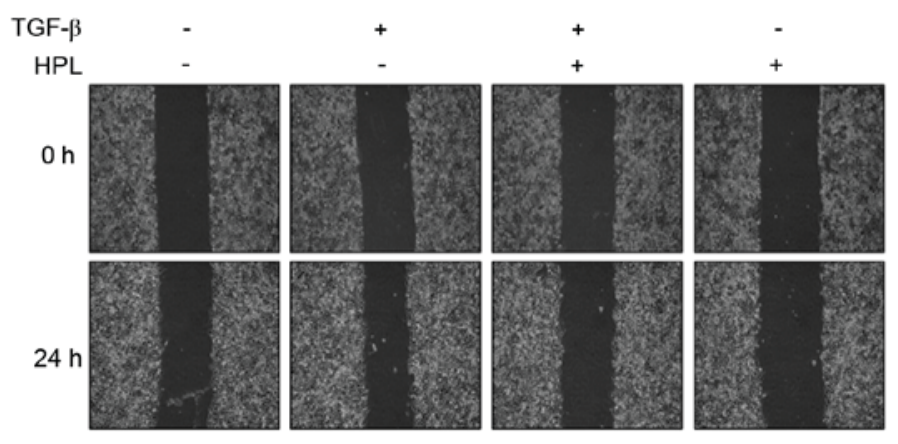

Figure 2. HPL inhibits TGF- $\beta$ induced cell migration of MCF-7 and A549 cells. (A) MCF-7 and (B) A549 cells were wounded by scratching with a pipette tip and then were incubated with or without $10 \mathrm{ng} / \mathrm{ml}$ TGF-b and HPL $(20 \mu \mathrm{M})$. Representative images of wound healing were captured at the time of scratching and following $24 \mathrm{~h}$. Cell migration into the wounded area was quantified as the fold ratio of wound healing $(\mathrm{n}=5)$ ) ${ }^{* * *} \mathrm{P}<0.01 \mathrm{vs}$. TGF- $\beta$ treated cells. HPL, hispolon; TGF- $\beta$, transforming growth factor $\beta$; n, number.

$(20 \mu \mathrm{M})$, and wound-healing assays were performed. The TGF- $\beta$-treated cancer cells exhibited a $\geq 1.2$-fold increase in migration, whereas treatment with $20 \mu \mathrm{M}$ HPL inhibited this TGF- $\beta$-induced migration by $45 \%$ for MCF- 7 and $50 \%$ for A549 cells (Fig. 2A and B). The inhibition of migration
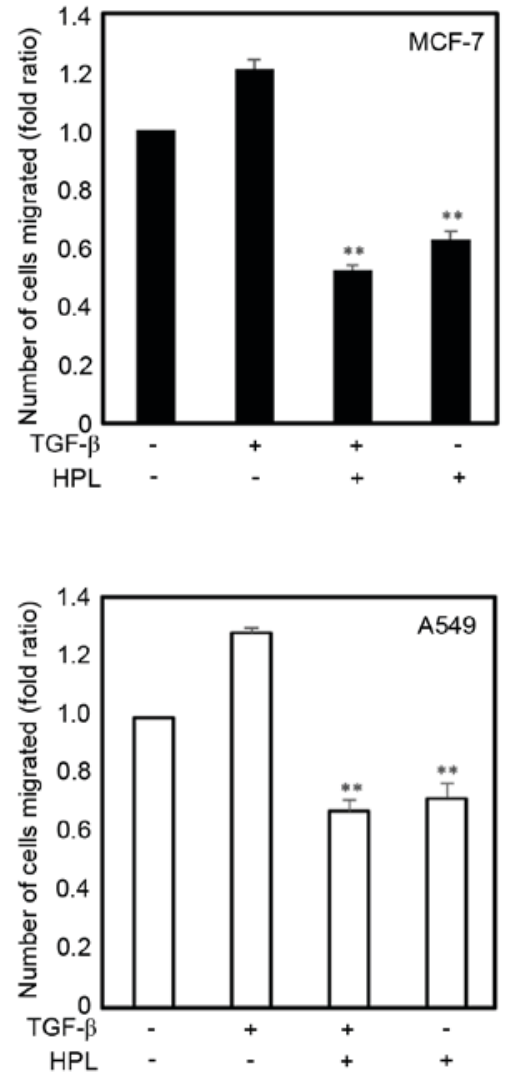

was also observed in the HPL alone treatment group, HPL decreased the migration by $60 \%$ for MCF- 7 and $65 \%$ for A549 cells compared with the untreated control group. These results revealed that HPL inhibited the migration of cancer cells during EMT induced by TGF- $\beta$. 
A
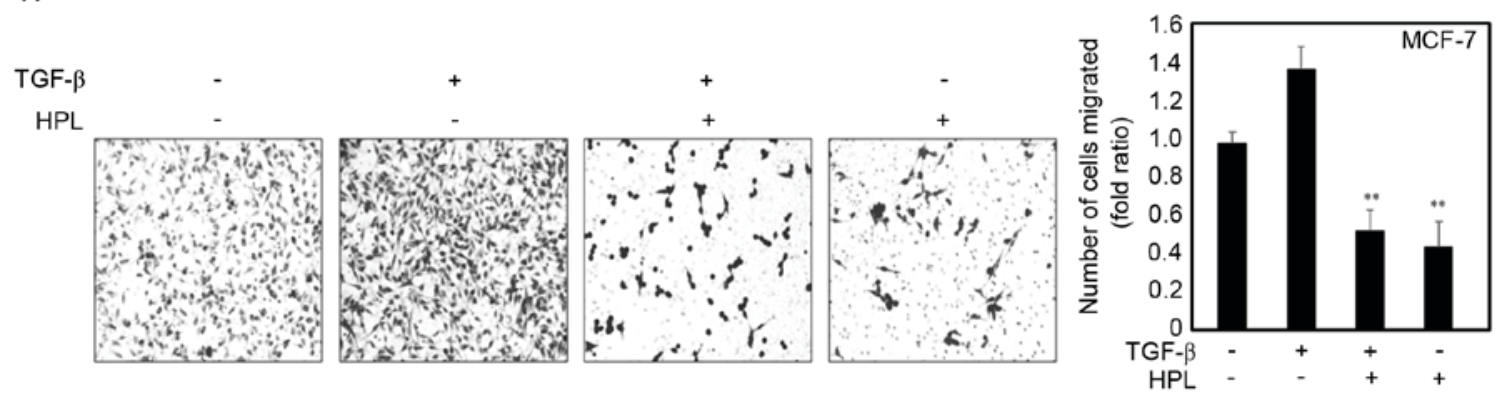

B
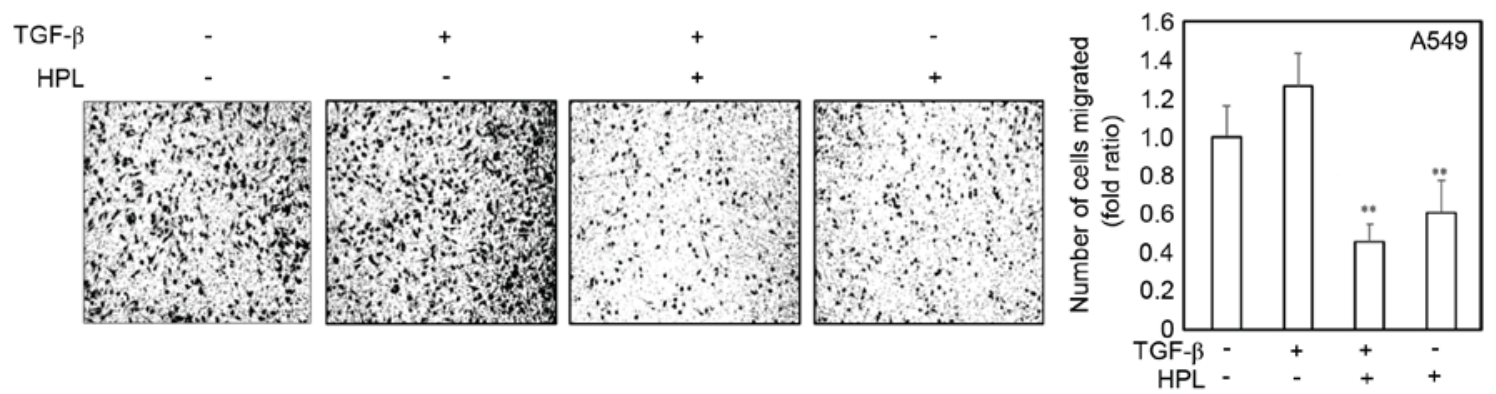

Figure 3. HPL inhibits cell invasion induced by TGF- $\beta$. (A) MCF-7 and (B) A549 cells treated with HPL (20 $\mu \mathrm{M})$ with or without $10 \mathrm{ng} / \mathrm{ml}$ TGF- $\beta$ for $24 \mathrm{~h}$. Invasion was determined using Transwell assays. Representative photomicrographs of membrane-associated cells stained with crystal violet. Cell invasion values were quantified as the fold ratio of invaded cells $(\mathrm{n}=5) .{ }^{* *} \mathrm{P}<0.01$ vs. TGF- $\beta$-treated cells. HPL, hispolon; TGF- $\beta$, transforming growth factor $\beta$; n, number.

Effect of HPL on the TGF- $\beta$-induced invasion of human cancer cells. The present study next investigated whether HPL inhibited the TGF- $\beta$-induced invasiveness of cancer cells. Following treatment with TGF- $\beta$ alone, the number of invasive cells significantly increased compared with the untreated cells. However, the number of invasive cells was significantly reduced in the cells treated with the combination of TGF- $\beta$ plus HPL (Fig. 3). The quantitative analysis is presented in Fig. 3. HPL significantly inhibited TGF- $\beta$-induced invasion of cancer cells by 50\% for MCF-7 and 40\% for A549 cells, compared with the untreated control group. These results suggested that HPL inhibits the effect of TGF- $\beta$, increasing the invasiveness of human cancer cells, as occurs during the EMT.

Effects of HPL on the expression level of E-cadherin. To further investigate the effect of HPL on TGF- $\beta$-induced EMT, the present study evaluated the expression levels of the EMT-associated protein, E-cadherin, by western blotting (Fig. 4A). The expression of E-cadherin was downregulated in the TGF- $\beta$-treated group compared with the controls. However, HPL reversed the TGF- $\beta$-induced EMT by reducing E-cadherin expression levels. The present study also determined the E-cadherin expression level in cancer cells by immunofluorescence (Fig. 4B). Consistent with the western blotting results, in the two cell types, E-cadherin was seldom expressed following TGF- $\beta$ treatment, but was significantly recovered by co-treatment with HPL. Taken together, the western blotting and fluorescence imaging results suggested that HPL has an inhibitory effect on EMT.

TGF- $\beta$-Snail/Twist signaling axis for reversal of TGF- $\beta$-induced EMT. Numerous previous studies have reported that drugs may inhibit the invasion and migration of cancer cells by suppressing TGF- $\beta$ activation and Snail/Twist induction, which results in recovering E-cadherin expression $(22,23)$. It was suggested that the TGF- $\beta$ signaling pathway is critically involved in the acquisition of EMT by its downstream target, the transcription factor Snail and Twist (24). The present study investigated the expression levels of the Snail and Twist proteins by western blotting to determine whether the effect of HPL described above is associated with the inhibition of the TGF- $\beta$-Snail/Twist axis. As presented in Fig. 4A, TGF- $\beta$ significantly upregulated the expression levels of Snail and Twist proteins, which reduced the expression level of E-cadherin. These effects were reduced by HPL, suggesting that HPL suppressed TGF- $\beta$-induced EMT by co-regulating Snail and Twist.

\section{Discussion}

The EMT is the most established example of the changes that occur in the patterns and functions of cancer cells (25). During the EMT, epithelial cells acquire mesenchymal features including increased motility, invasiveness and a heightened resistance to apoptosis, instead of losing their differentiated characteristics including cell-cell adhesion and apical-basal polarity (26). These alterations, particularly the reduction in intercellular adhesion and increase in motility, result in metastasis, enabling these cells to break through the basal membrane and migrate over long distances (27). In addition, EMT is considered to be an important process in the invasive cascade, facilitating the migration of tumor cells from their site of origin and their dissemination to distant tissues (28). As EMT serves a role in enhancing the invasive and metastatic 
A
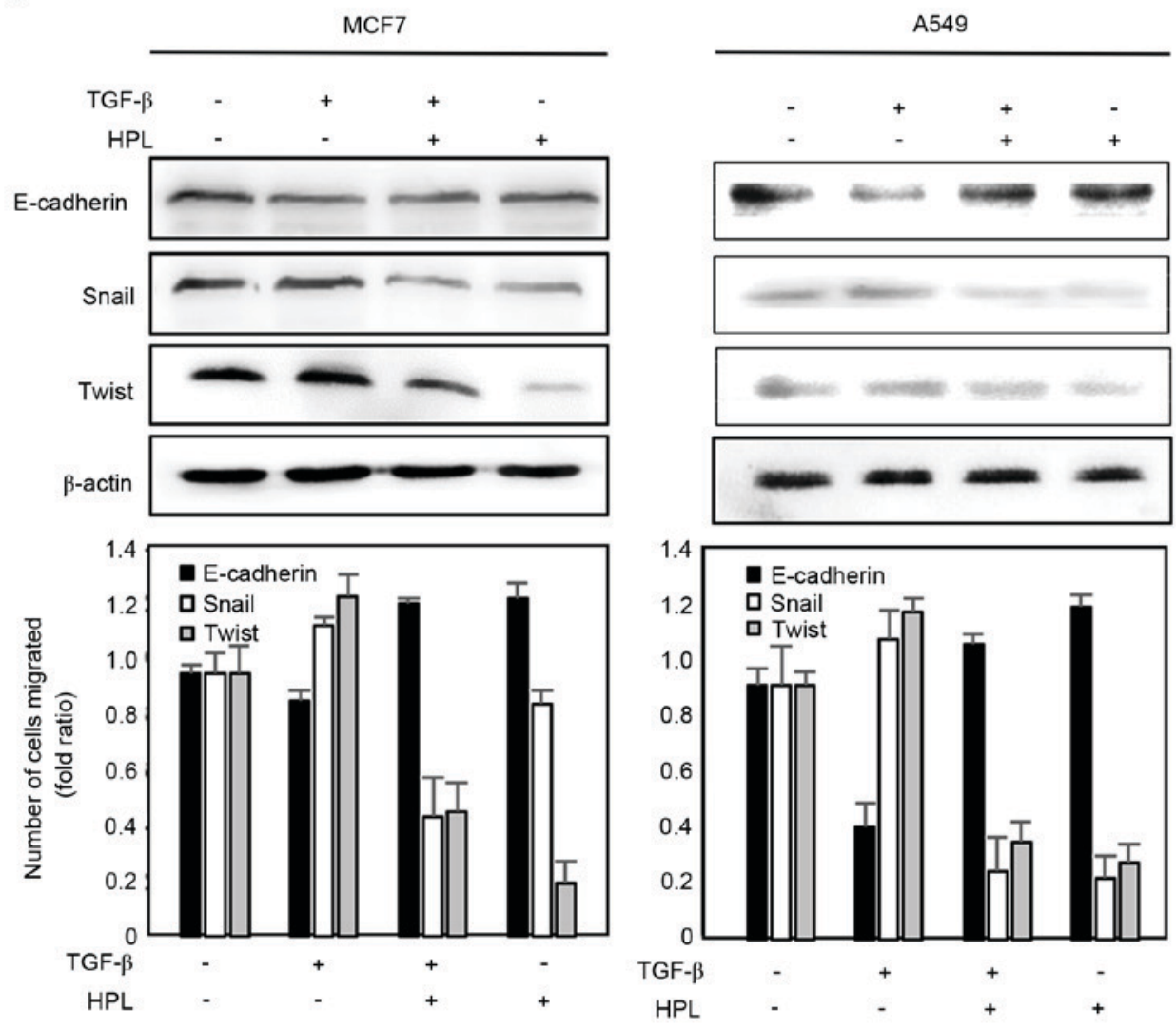

B
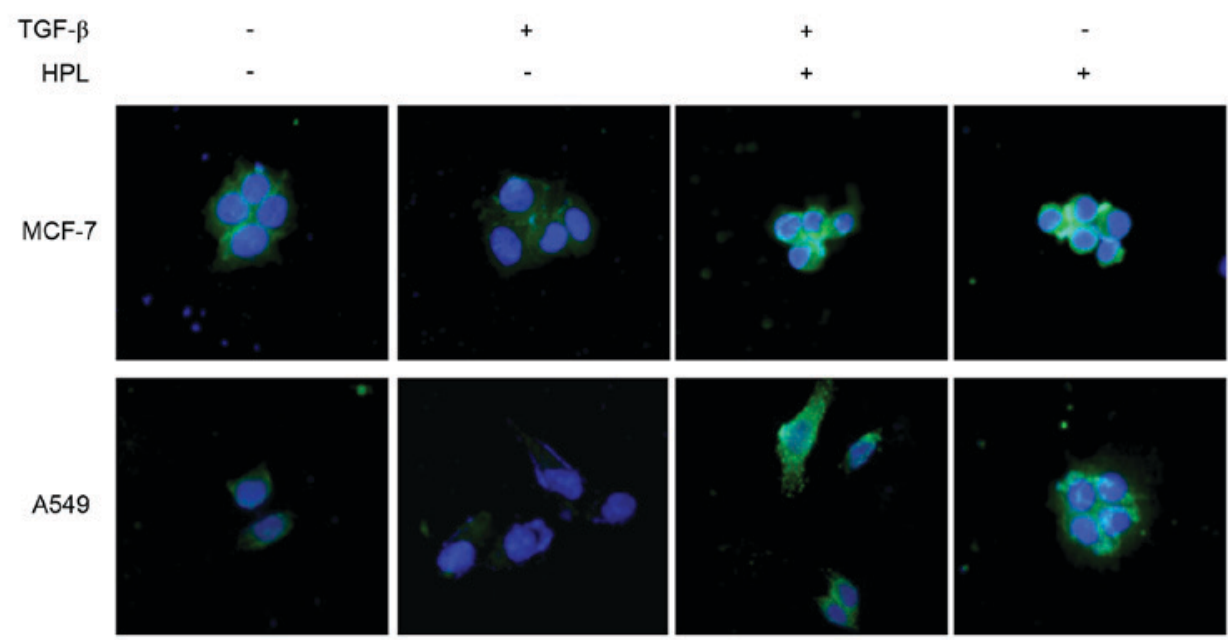

Figure 4. HPL regulates the expression level of EMT-associated proteins and inhibits the activation of TGF- $\beta$-Snail/Twist signaling. (A) Expression level of E-cadherin, Snail and Twist proteins in MCF-7 and A549 cells was determined by western blotting. (B) MCF-7 and A549 cells were immunostained with anti-E-cadherin antibody (green color) and the nuclei were counterstained with DAPI (blue color) following HPL treatment. HPL, hispolon; TGF- $\beta$, transforming growth factor $\beta$.

behavior of cancer cells, inhibition of EMT is a suitable strategy for cancer chemotherapy, particularly metastasis.

As previously reported, TGF- $\beta$ induces EMT in various types of cancer cells, increasing their invasion and migration and resulting in enhanced metastasis $(22,23,29)$. The present study demonstrated that MCF-7 and A549 human cancer cells may be induced by TGF- $\beta$ to undergo a stimulated EMT, reducing E-cadherin expression level in cancer cells and increasing their invasiveness and migration. HPL inhibited the action of TGF- $\beta$ in inducing the EMT, reversing the altered expression level of proteins associated with cell invasion and migration. The present study also revealed that Snail/Twist signaling may be required for TGF- $\beta$-induced EMT in cancer cells, which further elucidates the mechanism underlying HPL inhibition of cancer cell metastasis.

HPL, derived from Phellinus linteus, is known for its anticancer properties, particularly with breast cancer modulating estrogen receptor $\alpha$, as previously reported (30). However, HPL 
has not been associated with cancer metastasis via the EMT, although its strong antitumor effects have been reported (31). To the best of our knowledge, this is the first study to demonstrate that the anti-metastatic effects of HPL are associated with the EMT in cultured human cancer cells. Therefore, the results of the present study suggested a novel anticancer activity for HPL in inhibiting the progression of cancer metastasis.

The present study demonstrated that HPL inhibited the TGF- $\beta$-induced EMT, and thus cell migration and invasion, which result from the dysregulation of cell-cell adhesion proteins and the expression levels of E-cadherin, an EMT-associated protein. E-cadherin is expressed by the majority of epithelial tissues, facilitates tight cell-cell adhesion and suppresses the dissociation of epithelial cells from their locations. The loss of E-cadherin expression correlates with the invasiveness and undifferentiated phenotype of numerous epithelium-derived cancer cells (32). Therefore, the loss of E-cadherin expression in cancer cells has functional significance in cancer progression and metastasis.

The results of the present study also revealed that the mechanism underlying HPL may involve suppression of TGF- $\beta$-Snail/Twist signaling axis. The changes in gene expression that contributed to the repression of the epithelial phenotype and activation of the mesenchymal phenotype involves the regulators Snail and Twist (33). Induction of Snail expression has been noted in all EMT processes that have been previously studied, and increased Snail levels have been correlated with more invasive tumor types (34-36). Snail regulated the expression level of epithelial or mesenchymal genes and it regulated the expression level of E-cadherin, which is downregulated during EMT (37). Twist, a helix-loop-helix protein, is a major regulator of mesoderm formation in Drosophila and neural tube closure in mice, suggesting its involvement in developmental EMT (38). Twist decreases E-cadherin expression levels and enhances cell migration and invasion $(39,40)$. The results of the present study support these previous findings and provided a mechanistic basis for the inhibition of tumor progression by HPL.

In conclusion, the present study demonstrated that HPL inhibition of tumor invasion and migration is associated with the EMT process during tumor progression, and is possibly mediated by suppression of the TGF- $\beta$-Snail/Twist signaling axis and regulating the expression level of E-cadherin, an important downstream EMT marker. Although further in vivo studies are required to establish the potential of HPL as a therapeutic agent, the present study suggested that HPL is an effective anticancer agent with inhibition of metastatic activity against epithelial tumors.

\section{Acknowledgements}

The present study was supported by the Basic Science Research Program of the National Research Foundation of Korea (NRF) funded by the Ministry of Education (grant no. 2014R1A1A2057861) and the Ministry of Science, ICT \& Future Planning (grant no. NRF-2013R1A1A1062292).

\section{References}

1. Siegel RL, Miller KD and Jemal A: Cancer statistics, 2015. CA Cancer J Clin 65: 5-29, 2015.
2. Sleeman JP, Nazarenko I and Thiele W: Do all roads lead to Rome? Routes to metastasis development. Int J Cancer 128: 2511-2526, 2011.

3. Steeg PS: Tumor metastasis: Mechanistic insights and clinical challenges. Nat Med 12: 895-904, 2006

4. Wang Y and Zhou BP: Epithelial-mesenchymal transition-A hallmark of breast cancer metastasis. Cancer Hallm 1: 38-49, 2013.

5. Bogenrieder T and Herlyn M: Axis of evil: Molecular mechanisms of cancer metastasis. Oncogene 22: 6524-6536, 2003.

6. Kong D, Li Y, Wang Z and Sarkar FH: Cancer stem cells and epithelial-to-mesenchymal transition (EMT)-phenotypic cells: Are they cousins or twins? Cancers (Basel) 3: 716-729, 2011.

7. Acloque H, Adams MS, Fishwick K, Bronner-Fraser M and Nieto MA: Epithelial-mesenchymal transitions: The importance of changing cell state in development and disease. J Clin Invest 119: 1438-1449, 2009.

8. Micalizzi DS, Farabaugh SM and Ford HL: Epithelialmesenchymal transition in cancer: Parallels between normal development and tumor progression. J Mammary Gland Biol Neoplasia 15: 117-134, 2010.

9. Polyak K and Weinberg RA: Transitions between epithelial and mesenchymal states: Acquisition of malignant and stem cell traits. Nat Rev Cancer 9: 265-273, 2009.

10. Thiery JP, Acloque H, Huang RY and Nieto MA: Epithelial-mesenchymal transitions in development and disease. Cell 139: 871-890, 2009.

11. Davis FM, Stewart TA, Thompson EW and Monteith GR: Targeting EMT in cancer: Opportunities for pharmacological intervention. Trends Pharmacol Sci 35: 479-488, 2014

12. Ginnebaugh KR, Ahmad A and Sarkar FH: The therapeutic potential of targeting the epithelial-mesenchymal transition in cancer. Expert Opin Ther Targets 18: 731-745, 2014.

13. Ali NA, Lüdtke J, Pilgrim H and Lindequist U: Inhibition of chemiluminescence response of human mononuclear cells and suppression of mitogen-induced proliferation of spleen lymphocytes of mice by hispolon and hispidin. Pharmazie 51: 667-670, 1996.

14. Huang GJ, Deng JS, Chiu CS, Liao JC, Hsieh WT, Sheu MJ and Wu CH: Hispolon protects against acute liver damage in the rat by inhibiting lipid peroxidation, proinflammatory cytokine and oxidative stress and downregulating the expressions of iNOS, COX-2 and MMP-9. Evid Based Complement Alternat Med 2012: 480714, 2012.

15. Yang LY, Shen SC, Cheng KT, Subbaraju GV, Chien CC and Chen YC: Hispolon inhibition of inflammatory apoptosis through reduction of iNOS/NO production via HO-1 induction in macrophages. J Ethnopharmacol 156: 61-72, 2014.

16. Chen W, Zhao Z, Li L, Wu B, Chen SF, Zhou H, Wang Y and $\mathrm{Li}$ YQ: Hispolon induces apoptosis in human gastric cancer cells through a ROS-mediated mitochondrial pathway. Free Radic Biol Med 45: 60-72, 2008.

17. Chen YC, Chang HY, Deng JS, Chen JJ, Huang SS, Lin IH, Kuo WL, Chao W and Huang GJ: Hispolon from Phellinus linteus induces G0/G1 cell cycle arrest and apoptosis in NB4 human leukaemia cells. Am J Chin Med 41: 1439-1457, 2013.

18. Chen YS, Lee SM, Lin CC and Liu CY: Hispolon decreases melanin production and induces apoptosis in melanoma cells through the downregulation of tyrosinase and microphthalmia-associated transcription factor (MITF) expressions and the activation of caspase-3, -8 and -9. Int J Mol Sci 15: 1201-1215, 2014.

19. Huang GJ, Deng JS, Huang SS and Hu ML: Hispolon induces apoptosis and cell cycle arrest of human hepatocellular carcinoma Hep3B cells by modulating ERK phosphorylation. J Agric Food Chem 59: 7104-7113, 2011.

20. Lu TL, Huang GJ, Lu TJ, Wu JB, Wu CH, Yang TC, Iizuka A and Chen YF: Hispolon from Phellinus linteus has antiproliferative effects via MDM2-recruited ERK1/2 activity in breast and bladder cancer cells. Food Chem Toxicol 47: 2013-2021, 2009.

21. Derynck R, Muthusamy BP and Saeteurn KY: Signaling pathway cooperation in TGF- $\beta$-induced epithelial-mesenchymal transition. Curr Opin Cell Biol 31: 56-66, 2014.

22. Drabsch Y and ten Dijke P: TGF- $\beta$ signalling and its role in cancer progression and metastasis. Cancer Metastasis Rev 31: 553-568, 2012.

23. Fabregat I, Fernando J, Mainez J and Sancho P: TGF-beta signaling in cancer treatment. Curr Pharm Des 20: 2934-2947, 2014.

24. Zavadil $\mathrm{J}$ and Böttinger EP: TGF-beta and epithelial-to-mesenchymal transitions. Oncogene 24: 5764-5774, 2005. 
25. Friedl $\mathrm{P}$ and Wolf $\mathrm{K}$ : Tumour-cell invasion and migration: Diversity and escape mechanisms. Nat Rev Cancer 3: 362-374, 2003.

26. De Craene B and Berx G: Regulatory networks defining EMT during cancer initiation and progression. Nat Rev Cancer 13: 97-110, 2013.

27. Kalluri R and Weinberg RA: The basics of epithelial-mesenchymal transition. J Clin Invest 119: 1420-1428, 2009.

28. Mulholland DJ, Kobayashi N, Ruscetti M, Zhi A, Tran LM, Huang J, Gleave $\mathrm{M}$ and Wu H: Pten loss and RAS/MAPK activation cooperate to promote EMT and metastasis initiated from prostate cancer stem/progenitor cells. Cancer research 72: 1878-1889, 2012

29. Principe DR, Doll JA, Bauer J, Jung B, Munshi HG, Bartholin L, Pasche B, Lee C and Grippo PJ: TGF- $\beta$ : Duality of function between tumor prevention and carcinogenesis. J Natl Cancer Inst 106: djt369, 2014.

30. Jang EH, Jang SY, Cho IH, Hong D, Jung B, Park MJ and Kim JH: Hispolon inhibits the growth of estrogen receptor positive human breast cancer cells through modulation of estrogen receptor alpha. Biochem Biophys Res Commun 463: 917-922, 2015.

31. Kim JH, Kim YC and Park B: Hispolon from Phellinus linteus induces apoptosis and sensitizes human cancer cells to the tumor necrosis factor-related apoptosis-inducing ligand through upregulation of death receptors. Oncol Rep 35: 1020-1026, 2016

32. Araki K, Shimura T, Suzuki H, Tsutsumi S, Wada W, Yajima T, Kobayahi T, Kubo N and Kuwano H: E/N-cadherin switch mediates cancer progression via TGF- $\beta$-induced epithelial-to-mesenchymal transition in extrahepatic cholangiocarcinoma. Br J Cancer 105: 1885-1893, 2011.
33. Lamouille S, Xu J and Derynck R: Molecular mechanisms of epithelial-mesenchymal transition. Nat Rev Mol Cell Biol 15: 178-196, 2014.

34. Li Z, Zhang L, Ma Z, Yang M, Tang J, Fu Y, Mao Y, Hong X and Zhang Y: ETV1 induces epithelial to mesenchymal transition in human gastric cancer cells through the upregulation of Snail expression. Oncol Rep 30: 2859-2863, 2013.

35. Masui T, Ota I, Yook JI, Mikami S, Yane K, Yamanaka T and Hosoi H: Snail-induced epithelial-mesenchymal transition promotes cancer stem cell-like phenotype in head and neck cancer cells. Int J Oncol 44: 693-699, 2014.

36. Xu J, Lamouille S and Derynck R: TGF-beta-induced epithelial to mesenchymal transition. Cell Res 19: 156-172, 2009.

37. Batlle E, Sancho E, Francí C, Domínguez D, Monfar M, Baulida J and García De Herreros A: The transcription factor snail is a repressor of E-cadherin gene expression in epithelial tumour cells. Nat Cell Biol 2: 84-89, 2000.

38. Yang MH, Wu MZ, Chiou SH, Chen PM, Chang SY, Liu CJ, Teng SC and Wu KJ: Direct regulation of TWIST by HIF-1alpha promotes metastasis. Nat Cell Biol 10: 295-305, 2008.

39. Chen ZF and Behringer RR: Twist is required in head mesenchyme for cranial neural tube morphogenesis. Genes Dev 9: 686-699, 1995

40. Yang J, Mani SA, Donaher JL, Ramaswamy S, Itzykson RA, Come C, Savagner P, Gitelman I, Richardson A and Weinberg RA: Twist, a master regulator of morphogenesis, plays an essential role in tumor metastasis. Cell 117: 927-939, 2004. 